\title{
Literatura y política
}

Antes de entrar a discutir la relación entre literatura y política, me gustaría dejar claro que prefiero tomar distancia frente a expresiones tales como aquella que reza que "toda literatura es política", la que, a mi juicio, deriva de otra parecida de claras connotaciones totalitarias: "todo es política". Esas afirmaciones lapidarias, fuera de su dudoso impacto grandilocuente, rápidamente nos llevan a atolladeros teóricos y éticos. Por supuesto que hay una literatura que no es política —es decir no expresamente política- que es perfectamente legítima y tiene todo el derecho de existir y ser leída.

Digo lo anterior porque supongo un ámbito propio y específico del quehacer político: el que atañe las relaciones de poder entre los seres humanos y el gobierno de la sociedad. Aunque éste es un terreno que no agota la realidad ni la integridad del ser humano sí las afecta de manera determinante. Entonces, cabe preguntarse si en el debate que se genera sobre este orden de cosas tiene cabida la actividad artística literaria $y$, de ser esto así, cuáles son las posibilidades de tener un impacto social significativo, dadas las condiciones actuales del quehacer literario en América Latina. Trataré de responder en orden a estas cuestiones.

En primer lugar, creo que puede haber, y de hecho ha habido, una parte de la actividad artística literaria de inclinación política, es decir, preocupada por ayudar a los seres humanos a esclarecer -estéticamente se entiende- los problemas derivados de su convivir en sociedad y, especialmente, del carácter conflictivo y antagónico de esa coexistencia. Esta es una preocupación que aparece en toda la discusión clásica en tomo a la mímesis, y que figura luego entre los literatos de la
Ilustración, pero adquiere su formulación modema en la estética realista decimonónica.

Debido a que esta estética se elaboró en un clima dominado por el cientificismo positivista, tuvo una primera formulación bastante confusa y reductiva. El problema estético se confundió con uno de orden epistemológico, y todas las pretensiones del realismo, y especialmente del Naturalismo, de convertirse en fuente de conocimiento sobre la vida en común de los seres humanos, se volvió irrelevante y aun irrisoria con el posterior desarrollo de las ciencias sociales. ¿Qué podía ofrecer el "laboratorio" de la novela de Zola y los naturalistas frente a unas ciencias sociales legitimadas e institucionalizadas?

Los intentos de Lukács por salvar al realismo de la bancarrota teórica resultaron infructuosos, pese a su sólida argumentación filosófica, principalmente por su empecinamento dogmático de negar la poéticas de vanguardias en el sistema artístico del siglo XX. Pero todavía peor, la elevación del "realismo" —etiquetado como "realismo socialista" - a la categoría de estética oficial del estalinismo, lo convirtió no sólo en una incómoda preceptiva sino en la excusa para burdas maniobras de censura y manipulación del trabajo creativo. Consecuentemente, pese a que la expresión artística de los problemas que afectan la convivencia entre los seres humanos ha permanecido en buena medida constante -pienso no sólo en la novela sino también en el teatro y en la cinematografía-, la fundamentación estética de esta preocupación se ha visto dificultada por el comprensible escrúpulo de no reincidir en las aberraciones antes mencionadas. 
Por otra parte, el compromiso sartreano fue un intento de superar esta situación pero trajo consigo vicios e insuficiencias propias. Pecó de una velada intolerancia, por cuanto el mismo Sartre excluyó implícitamente aquellas manifestaciones artisticas no-comprometidas, incluso a algunas por petición de principio, como fue el caso de la poesía lírica. Por otra parte, el compromiso tendió a reducirse a un compromiso explícito en la persona del autor $y$, por lo tanto, dio origen a gestos histriónicos con frecuencia crudamente refutados por los actos.

El libro Teorías del realismo literario del español Darío Villanueva -recientemente vertido al inglés como Theories of Literary Realism (SUNY Press, Albany, 1997) — aporta algunos elementos para fundamentar una estética abocada hacia lo "político", sin recaer en la servidumbre ideológica, en la preceptiva, o en la confusión entre el aporte artístico y los compromisos explícitos asumidos por la persona del artista. Villanueva se distancia de lo que denomina realismo genético, es decir, aquel preocupado por "representar fielmente la realidad". Prefiere, en cambio, hablar de un realismo "intencional". Aquí este término se emplea no en el sentido de una "intención explícita del autor", sino en el de un juego de lenguaje en que la configuración textual involucra al receptor. En esta formulación, el problema del realismo no radica ya en "representar" o "reflejar" la realidad "fielmente", sino en remitir al lector a su entorno experiencial por medio de los recursos literarios (se vuelve innecesario prescribirlos porque dependen de la creatividad e imaginación del escritor y de la competencia literaria del lector) que le permitan ampliar su horizonte de aprehensión de lo real. De esta forma, Villanueva intenta incorporar la dialéctica entre innovación formal y referencialidad que las teorías tradicionales del realismo soslayan.

Desde esta perspectiva, por ejemplo, el llamado realismo mágico latinoamericano —o para usar una expresión que estimo más precisa, la estética de lo real-maravilloso-, puede entenderse como un verdadero realismo. Es un nuevo realismo que nos abre a una dimensión de lo real en los entomos periféricos al capitalismo que el "racionalismo" estrecho de la novelística decimonónica estaba imposibilitada de aprehender: la coexistencia de diversas temporalidades en un mismo espacio social como expresión de heterogeneidad cultural y del carácter paradójico de la modemización en estos contextos. En otras palabras, este "realismo" capta estéticamente el fenómeno de la "asincronicidad" al que aludió Emst Bloch en alguna ocasión. Esta característica obliga necesariamente a ampliar la noción de lo "real", para lo cual el realismo ortodoxo resulta estéticamente inadecuado. Operaciones análogas se han dado en el terreno del pensamiento filosófico y social con el creciente interés en la efectividad real de lo "imaginario" que encontramos en el trabajo de un Comelius Castoriadis o un Etienne Balibar.

No dejar de aseverar, que a mi entender, la estética de lo "real-maravilloso" se encuentra en la actualidad en proceso de agotamiento. Ello es resultado de procesos internos y externos respecto del sistema literario. Entre las causas intemas hay que mencionar un claro proceso de "banalización" del realismo mágico. Cada vez son más los autores que encuentran en esta vertiente un rentable filón para colocar en el mercado de los bienes culturales sus obras. Así, el realismo-mágico se asocia cada vez más con la satisfacción de la sed de exotismo por parte de lectores "sofisticados", se convierte así en una nueva estrategia de ocultación estética de lo real y no de su revelación. Pero tampoco deben subestimarse las causas externas. Las realidades de los países periféricos están cambiando acelerada y drásticamente. El nuevo peso de lo urbano y el impacto cada vez más universal de los mass media en la vida cotidiana reclama de nuevas configuraciones para ser aprehendida estéticamente.

Pese a lo anterior, valga el ejemplo de la estética de lo "real-maravilloso" para mostrar cómo una práctica artística puede ser, por una parte, innovadora desde un punto de vista estético y remitir, por la otra, a dimensiones de lo real que tienen especial repercusión política. Las posibilidades para una praxis estética de esta naturaleza no están en lo absoluto agotadas. Más aún, me atrevo a afirmar, contra quienes postulan la muerte del arte, que son inagotables por cuanto la realidad misma es inagotable. Sin embargo, creo que las actuales condiciones de organización de la institución literaria en América Latina frustran en buena parte esas posibilidades y, explican, en gran parte, cierta pérdida de originalidad y vitalidad en la literatura latinoamericana del llamado "post-boom".

En las décadas de 1960 y 1970, fue posible una literatura que conjugara la calidad estética con el "compromiso" en América Latina, porque 


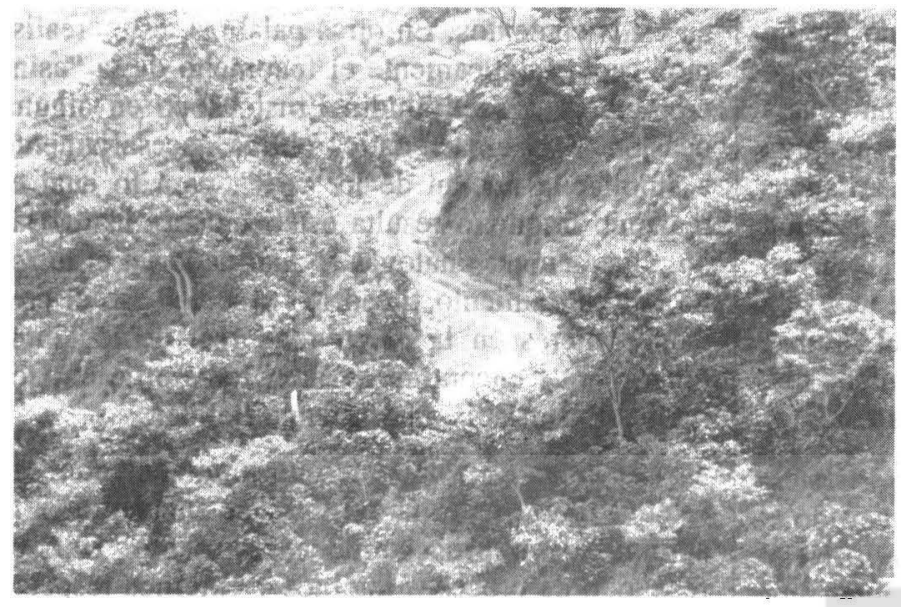

padecido el totalitarismo, el reclamo de un ámbito personal ha sido una imperiosa responsabilidad política. Por otra parte, considero que cierto tipo de literatura de "denuncia" que se apoya en clichés fáciles y lugares comunes es un claro ejemplo de ocultación de lo real.

Con todo, la crisis actual de paradigmas y ciertas modas posmodernas han traído, como consecuencia, bastante clara la vigencia y prestigio de planteamientos donde se proclama de manera bastante poco ambigua la inaccesibilidad de lo real, la imesponsabilidad y el refugio narcisista en el yo. Todas estas ideas venden porque son efectivas

existía una identificación considerable por parte de los sectores medios - aquellos con posibilidad de acceso a cultura estética - con los proyectos de izquierda, fueran éstos de corte reformista o revolucionario. Hoy en día, al finalizar la década de 1990 , los cambios experimentados en el terreno de la producción literaria reflejan, al menos en parte, cambios importantes en estos grupos consumidores de cultura. Los cuales, a su vez, explican por qué en la actualidad existe una menor independencia de los escritores frente a los imperativos económicos del mercado editorial.

La institución literaria en América Latina está dejando de desempeñar una función determinante en la potenciación del horizonte de aprehensión de lo real del público lector, y se está convirtiendo cada vez más en un mercado de bienes de prestigio social. Para ponerlo en cristiano: la gente ya no tiende a leer porque busque mayor lucidez, sino que consume libros que son distintivos asociados con la pertenencia a ciertas élites. No es de extrañar que la preocupación política, el impulso comprometido, sea una de las bajas más notorias. La necesidad de afirmar la libertad artística contra algunos de los excesos infringidos en aras del "compromiso" ha llevado al otro extremo: a la celebración de la fuga narcisista de lo real y, en ciertos casos (pienso en algunos ejemplos salvadoreños bastante reveladores que me reservo de nombrar) simplemente de la irresponsabilidad. Aquí se vuelve necesaria un aclaración y es que no considero que la literatura de tono íntimo, donde se explore la dimensión personal de la realidad, sea necesariamente una "fuga narcisista de lo real". Más aún, en sociedades que padecen o han en halagar la autocomplacencia de un lector sumido en un mundo que hoy por hoy resulta bastante confuso e incomprensible.

Pienso, por otra parte, que sería iluso revivir artificialmente el optimismo de las décadas antes mencionadas y, sobre todo, la fe en los grandes relatos, que en América Latina quiere decir cierta certeza mística en una cercana transformación sustancial del orden social. Hay razones objetivas que vuelven esa fe ilusoria. Pienso, sin embargo, que precisamente el aceptar esta realidad vuelve más urgente una redefinición de la relación entre literatura y política. $O$ si se prefiere una redefinición del concepto mismo de "compromiso".

El compromiso de la literatura actual (o por lo menos de cierta literatura) no debe ser con las utopías con mayúscula ni con los grandes relatos. Ello no niega, sin embargo, cierta dimensión utópica - en el sentido débil de la palabra - de compromiso con lo "real", y sobre todo de "autenticidad" con la experiencia de lo "real". Creo razonable, al menos como crítico, esperar que la literatura nos remita a lo real, que nos presente lo real en sus dimensiones inéditas e insospechadas, que nos lleve a lo otro, a lo aquello que no somos nosotros mismos. Siendo lo "político" un componente importante de lo real, podemos esperar razonablemente que exista un literatura que nos remita a lo político, aunque casi seguramente no nos remitirá a lo político convencional, sino a dimensiones nuevas que amplíen y renueven nuestra concepción misma de la política y del hacer política. Simultáneamente, como crítico, creo estar obligado a señalar cuándo - a mi juicio- una 
obra o moda literaria me oculta lo real y me ofrece el fácil refugio de lo mismo con distintos ropajes.

Karl Kraus solía decir que ser artista no sólo implica una habilidad formal sino una talla moral. Esto nos lleva a la distinción clásica entre retórica y poética. El retórico es el habilidoso con la palabra, pero que usa finalmente la palabra como un instrumento, la fermosa cobertura de la mentira, la tramposa seducción del lector. Ser poeta presupone una destreza (pensemos en la etimología de poesía), pero que no es suficiente. Requiere de una autenticidad de la expresión que posibilita la epifanía de lo real en la lectura de la obra. La talla moral del poeta es este compromiso artístico con lo real, la única manera de conjurar el espectro de la irrelevancia en la literatura latinoamericana para el futuro.

Ricardo Roque Baldovinos 